University of Nebraska - Lincoln

DigitalCommons@University of Nebraska - Lincoln

Finance Department Faculty Publications

Finance Department

2010

Executive Compensation and the Maturity Structure of Corporate Debt

Paul Brockman

Lehigh University, pab309@lehigh.edu

Xiumin Martin

Washington University, XMartin@WUSTL.EDU

Emre Unlu

University of Nebraska-Lincoln, emre@unl.edu

Follow this and additional works at: https://digitalcommons.unl.edu/financefacpub

Part of the Finance and Financial Management Commons

Brockman, Paul; Martin, Xiumin; and Unlu, Emre, "Executive Compensation and the Maturity Structure of Corporate Debt" (2010). Finance Department Faculty Publications. 21.

https://digitalcommons.unl.edu/financefacpub/21

This Article is brought to you for free and open access by the Finance Department at DigitalCommons@University of Nebraska - Lincoln. It has been accepted for inclusion in Finance Department Faculty Publications by an authorized administrator of DigitalCommons@University of Nebraska - Lincoln. 


\title{
Executive Compensation and the Maturity Structure of Corporate Debt
}

\author{
PAUL BROCKMAN, XIUMIN MARTIN, and EMRE UNLU*
}

\begin{abstract}
Executive compensation influences managerial risk preferences through executives' portfolio sensitivities to changes in stock prices (delta) and stock return volatility (vega). Large deltas discourage managerial risk-taking, while large vegas encourage risk-taking. Theory suggests that short-maturity debt mitigates agency costs of debt by constraining managerial risk preferences. We posit and find evidence of a negative (positive) relation between CEO portfolio deltas (vegas) and short-maturity debt. We also find that shortmaturity debt mitigates the influence of vega- and delta-related incentives on bond yields. Overall, our empirical evidence shows that short-term debt mitigates agency costs of debt arising from compensation risk.
\end{abstract}

JEL: G30; G32

Keywords: Executive compensation; Agency costs; Debt maturity

* Lehigh University, Washington University, and University of Nebraska. The authors thank an anonymous referee and associate editor, the editor (Campbell R. Harvey), and co-editor (John R. Graham) for their suggestions and comments during the revision process. The authors also thank Mary McGarvey, James Schmidt and seminar participants at Washington University, University of Missouri, Texas Christian University, and University of Texas-Dallas for their comments. 
The use of stock- and option-based executive compensation has increased dramatically during the past few decades. The median exposure of CEO wealth to stock prices tripled between 1980 and 1994 (Hall and Liebman (1998)), and then doubled again between 1994 and 2000 (Bergstresser and Philippon (2006)). Such changes in executive compensation have a direct impact on the manager's exposure to risk, thus altering both incentives and behavior. Carpenter (2000) and Lambert, Larcker, and Verrecchia (1991) discuss two effects of compensation on managerial incentives. One effect is caused by the sensitivity of compensation to stock prices (delta). A second effect is caused by the sensitivity of compensation to stock return volatility (vega). The higher the compensation package's sensitivity to stock prices, the weaker will be the manager's appetite for risk (Knopf, Nam, and Thornton (2002)). In contrast, the higher the compensation package's sensitivity to stock return volatility, the stronger will be the manager's appetite for risk (Knopf, Nam, and Thornton (2002), Coles, Daniel, and Naveen (2006)). By altering managerial risk preferences, stock-based compensation also influences third-party (e.g., creditors, suppliers, customers) perceptions of those risk preferences. The primary objective of this study is to investigate the role of short-term debt in reducing agency costs of debt arising from executive incentive contracts. Specifically, we examine the effect of the two portfolio sensitivities on the maturity structure of corporate debt. In addition, we analyze the effect of debt maturity on the relation between portfolio sensitivities and bond yields. The empirical results provide a consistent picture that short-term debt reduces agency costs of debt associated with compensation incentives.

Traditional agency theory posits a conflict of interest between shareholders and creditors. In their seminal studies, Fama and Miller (1972) and Jensen and Meckling (1976) show that shareholders have an incentive to expropriate bondholder wealth by substituting into riskier 
investments, a phenomenon commonly referred to as asset substitution. Equity-based compensation provides managers with a potentially stronger motive for asset substitution. Creditors understand these risk incentives and rationally price them. For example, credit rating agency reports show an awareness of the link between CEO compensation and managerial risk appetites. A 2007 Moody's Investors Service Special Comment states that "Executive pay is incorporated into Moody's credit analysis of rated issuers because compensation is a determinant of management behavior that affects indirectly credit quality (p. 1)." The report later explains that the "primary interest in analyzing pay is to gain insight into the compensation committee's intent regarding the structure, size and focus of incentives (p. 4)." Moody's has also published the results of an internal study conducted in 2005 entitled CEO Compensation and Credit Risk. This study concludes that "pay packages that are highly sensitive to stock price and/or operating performance may induce greater risk taking by managers, perhaps consistent with stockholders' objectives, but not necessarily bondholders' objectives (p. 8)." We find similar statements regarding CEO incentives and credit analysis in Standard \& Poor's reports. ${ }^{1}$

Barnea, Haugen, and Senbet (1980) argue that shorter-term debt can reduce managerial incentives to increase risk. Further, Leland and Toft (1996) claim that short-term debt can reduce or even eliminate agency costs associated with asset substitution. ${ }^{2}$ An important insight from Stulz (2000) is that short-term debt provides creditors with "an extremely powerful tool to monitor management." Similarly, Rajan and Winton (1995) argue that short-term debt provides creditors with additional flexibility to monitor managers with minimum effort.

Using two measures of risk preference derived from managerial compensation packages in this paper, we test the role of short-term debt in mitigating agency costs of debt arising from asset substitution. Specifically, we posit that the proportion of short-term debt increases in CEO 
compensation risk. One measure of the manager's appetite for risk is the sensitivity of the compensation package to underlying stock prices. Creditors recognize that the lower this sensitivity, the more likely the manager is to engage in risk-increasing strategies. We therefore expect that the lower the manager's sensitivity to stock prices, the larger the proportion of shortterm debt in the firm's capital structure. In contrast, the manager's appetite for risk increases with the sensitivity of the compensation package to stock return volatility. We therefore expect that the higher the manager's sensitivity to stock return volatility, the larger the proportion of short-term debt in the firm's capital structure. Prior studies argue and find some evidence that the cost of debt increases in managerial compensation risk (e.g., Daniel, Martin, and Naveen (2004), Billet, King, and Mauer (2007), and Shaw (2007)). If short maturities restrain managerial riskseeking, then we expect that short-term debt will attenuate the effect of compensation risk on the cost of debt.

We study the causal link between CEO incentive compensation and corporate debt maturity using a sample of 6,825 firm-year observations during the 14-year period from 1992 to 2005. We employ alternative definitions of short-term debt, follow Core and Guay's (2002) method for estimating option sensitivities, ${ }^{3}$ and apply several empirical methodologies (e.g., pooled OLS and GMM simultaneous equation estimation, fixed-effect regressions, and changein-variables regressions) and an alternative new debt issuance sample to analyze the predicted relations. As hypothesized, we find a negative and significant relation between CEO portfolio deltas and short-term debt. Also consistent with expectations, we find a positive and significant relation between CEO portfolio vegas and short-term debt. Taken together, these findings suggest that short-term debt is used to reduce agency costs associated with high managerial compensation risk. Our empirical results are robust to controlling for CEO stock ownership, 
leverage, asset maturity, growth opportunities, firm size, term structure, bond rating, and other issuer characteristics.

Next, we use a sample of 268,400 bond-day observations for 114 unique firms during the 1994 to 2005 period to examine whether short-maturity debt mitigates the impact of managerial incentives on the cost of debt. Consistent with prior studies (e.g., Billett, Mauer, and Zhang (2009), Daniel, Martin, and Naveen (2004), Shaw (2007)), we find that higher deltas (vegas) lead to lower (higher) borrowing costs. More importantly, we show that short-term debt attenuates the negative (positive) relation between bond yields and deltas (vegas).

Our study makes several contributions to the literature. First, we provide empirical support for theory that argues that short-maturity debt mitigates agency costs of debt related to asset substitution (Barnea, Haugen, and Senbet (1980), Leland and Toft (1996)). Related research by Johnson (2003) finds that short-term debt mitigates the debt overhang problem for high growth firms. Our paper complements this finding by showing that short-term debt can also mitigate asset substitution problems for firms with high CEO compensation risk.

Our empirical results also add to the literature on the maturity structure of corporate debt. Barclay and Smith (1995), Guedes and Opler (1996), and Stohs and Mauer (1996), among others, find that debt maturity is determined by firm characteristics such as asset maturity, growth opportunities, and firm size. Datta, Iskandar-Datta, and Raman (2005) provide evidence that managerial ownership is an additional determinant of corporate debt maturity. Our study extends this literature by showing that CEO compensation incentives also affect debt maturity structure.

Next, we expand our understanding of how managerial compensation characteristics impact corporate capital structure. Berger, Ofek, and Yermack (1997) document that firms with weak managerial incentives avoid high levels of leverage. Novaes and Zingales (1995) show that 
the optimal level of leverage for shareholders differs from that chosen by entrenched managers. Datta, Iskandar-Datta, and Raman (2005) document that managerial stock ownership inversely affects debt maturity. Our study provides new evidence that the two sensitivities of managerial compensation affect debt maturity in different ways: the sensitivity of CEO wealth to stock price increases debt maturity, whereas the sensitivity of CEO wealth to stock return volatility reduces debt maturity.

Finally, our study sheds light on creditors' assessment of managerial incentives and riskseeking behavior. Option-based compensation is designed in part to encourage risk-averse, underdiversified managers to invest in positive but risky NPV projects. However, it is an open question as to whether option-based compensation might also encourage excessive risk-taking, thus aggravating stockholder-debtholder conflicts. John and John (1993) and Parrino and Weisbach (1999) find evidence that suggests option-based compensation may increase risktaking, whereas Carpenter (2000), Ross (2004), and Hanlon, Rajgopal, and Shevlin (2004) find no such relation. Our empirical results confirm that creditors take into consideration the impact of option-based compensation on managerial risk-seeking behavior and adjust debt maturity and yield spreads accordingly.

This paper proceeds as follows. In Section I, we review related research and develop our testable hypotheses. Section II discusses the sample and data. We present our empirical findings in Section III, and we summarize and conclude in Section IV.

\section{Related Research and Hypotheses}

\section{A. Related Research}


Lambert, Larcker, and Verrecchia (1991) suggest that measuring the partial derivative (or, sensitivity) of the change in managerial compensation with respect to a change in a performance variable is the preferred way to assess managerial incentives. Recent empirical research examines the relation between CEO portfolio sensitivities and the firm's investment decisions. Guay (1999) finds that the sensitivity of CEO portfolios to stock return volatility is positively related to the firm's growth opportunities. Similarly, Rajgopal and Shevlin (2002) find that greater sensitivity of CEO options to stock return volatility is related to greater exploration risk and less risk hedging for a sample of oil and gas industry firms. Further, Hanlon, Rajgopal, and Shevlin (2004) show that firms with CEO option portfolios that are more sensitive to stock return volatility have greater one-year ahead stock return volatility, though such effects are economically small. Coles, Daniel, and Naveen (2006) endogenize CEO compensation and a firm's financial and investment policies and find that greater sensitivity of CEO wealth to stock return volatility is associated with higher leverage, larger research and development expenditures, and less capital expenditures. Taken together, these findings support the claim that option-based sensitivities exert significant influence on managerial decision-making.

Knopf, Nam, and Thornton (2002) disentangle the opposing effects of portfolio sensitivities on the manager's appetite for risk. They argue that the "sensitivity to stock return volatility should, ceteris paribus, give the manager an incentive to take more risk" (p. 801), while the "sensitivity to stock price should give a risk-averse manager an incentive to avoid risk" (p. 802). They find that managers with high portfolio sensitivities to stock return volatility tend to hedge less with derivative securities than managers with relatively low sensitivities. This finding supports the vega effect of executive compensation. They also show that managers with 
high portfolio sensitivities to stock prices (i.e., deltas) tend to hedge more with derivative securities than managers with low sensitivities.

There is considerable evidence that creditors understand the effect of price and volatility sensitivities on the CEO's risk-seeking behavior. Billett, Mauer, and Zhang (2009) find that when firms announce new CEO stock option grants, stockholders experience positive abnormal returns while bondholders experience negative abnormal returns. Bondholder returns are more negative with high vega stock option grants and less negative with high delta option grants. Daniel, Martin, and Naveen (2004) examine the impact of the CEO's delta and vega on the firm's cost of capital. They conclude that these CEO incentives affect the firm's cost of debt because "the bond markets understand and account for the effect of incentives on risk-taking" (p. $5)$.

Barnea, Haugen, and Senbet (1980) argue that "with rational expectations, debt-holders recognize the entrepreneur's incentive problem, and discount debt value accordingly.... In the absence of mechanisms which resolve the incentive problem, the entrepreneur incurs the agency costs" (p. 1229). The authors note that the risk incentive problem can be solved by shortening debt maturity. Lelend and Toft (1996) similarly argue that short-maturity debt reduces or eliminates asset substitution agency costs. Short-term debt has also been shown to reduce agency costs of managerial discretion by subjecting managers to more frequent monitoring by underwriters, investors, and rating agencies (Stulz (2000) and Rajan and Winton (1995)).

In this study, we follow Knopf, Nam, and Thornton's (2002) framework and extend the above literature by examining the impact of both dimensions of compensation risk (i.e., vega and delta effects) on the firm's debt maturity. Similar to Johnson (2003), we argue that short-term debt can be used to mitigate bondholder-shareholder conflicts. However, whereas Johnson 
examines the underinvestment agency problem caused by growth opportunities, we examine the asset substitution agency problem caused by the incentive structure of executive compensation. Without the use of short-term debt, managers with high vega (risk-seeking) incentives would bear higher agency costs and find it more difficult to access the credit markets. Berlin (2006) summarizes this relation between risk and maturity as follows (p. 4): "For some very risky firms, lenders are simply unwilling to lend long term because lenders will lose money too often ... As a result, lenders will provide only very short-term financing for such firms to keep them on a short leash." Like a short leash, short maturities can mitigate principal-agent problems.

\section{B. Hypotheses}

Although linking managerial compensation to firm performance by managerial stock and option ownership reduces owner-manager conflicts of interest, it may exacerbate owner-creditor conflicts. Previous empirical studies suggest that compensation contracts have two opposing effects on managerial incentives. The first effect is the sensitivity of the compensation package to movements in the underlying stock price. Tying a manager's wealth to the firm's stock price decreases a risk-averse manager's appetite for risk. The second effect is the sensitivity of the compensation package to stock return volatility. Due to the convex payoff structure of options, the value of a manager's stock option portfolio increases with the volatility of the firm's stock returns. Thus, tying managerial wealth to stock returns increases a risk-averse manager's appetite for risk.

Previous theoretical research also argues that asset substitution problems can be mitigated through the use of short-maturity debt since the value of shorter-term debt is less sensitive to shifts from low to high variance projects. Building on these arguments and previous empirical evidence, we posit that the maturity structure of debt can be used to mitigate compensation- 
related agency costs of debt for firms with high managerial compensation risk. ${ }^{4}$ Our first hypotheses can be stated as follows:

H1a: The proportion of short-term debt is negatively related to the sensitivity of the CEO's portfolio to stock prices (delta).

H1b: The proportion of short-term debt is positively related to the sensitivity of the CEO's portfolio to stock return volatility (vega).

Prior studies posit and find evidence of a positive relation between managerial risk seeking behavior and the cost of debt (Barnea, Haugen, and Senbet (1980), Daniel, Martin, and Naveen (2004), Billet, King, and Mauer (2007), and Shaw (2007)). If short-maturity debt discourages risk-tolerant managers from shifting towards risky projects and allows creditors to monitor managers with less effort, then we expect short-term debt to attenuate the positive relation between compensation risk and the cost of debt. Our second hypothesis can thus be stated as follows:

$\mathrm{H} 2$ : The proportion of short-term debt reduces the positive (negative) relation between vega (delta) and the cost of debt.

\section{Data and Variables}

\section{A. Data Sources and Sample Selection}

We construct two samples to test our main hypotheses, namely, a debt maturity sample to test $\mathrm{H} 1 \mathrm{a}$ and $\mathrm{H} 1 \mathrm{~b}$, and a bond yield sample to test $\mathrm{H} 2$. We draw archival data from various sources to construct the debt maturity sample. Specifically, we collect CEO compensation and ownership information from Standard and Poor's ExecuComp database. Financial accounting and stock return information come from COMPUSTAT annual files and CRSP monthly files, respectively. Yields on long-term government bonds are from the St. Louis Federal Reserve Bank website. ${ }^{5}$ 
We construct the debt maturity sample (to test $\mathrm{H} 1 \mathrm{a}$ and $\mathrm{H} 1 \mathrm{~b}$ ) by identifying the CEO of each firm in ExecuComp over the 1992 to 2005 period. We require that all necessary information be available to compute the price and volatility sensitivities of the CEO's option portfolio as well as the CEO's stock ownership. Next, we match the initial sample to COMPUSTAT and CRSP. Following prior literature (Barclay and Smith (1995), Datta, Iskandar-Datta, and Raman (2005)) we restrict our sample to industrial firms with SIC codes from 2000 and $5999 .{ }^{6}$ To be included in the final sample we require that all variables used in the study (discussed in the following sections) be available. We delete the few observations for which debt maturity is potentially erroneous (less than $0 \%$ or greater than $100 \%$ ). To eliminate the effect of outliers, we winsorize all variables at $1 \%$ and $99 \%$ of each variable's empirical distribution. Our final sample contains 6,825 firm-year observations based on 1,312 unique firms.

To construct our bond yield sample (to test H2), we identify publicly traded bonds of our sample firms using the Mergent Fixed Income Securities database. Following previous literature, we exclude bond issues with special features (e.g., call, put, sinking fund, convertible, credit enhancement, floating-rate coupon). ${ }^{7}$ We retrieve daily bond yields from Thomson's Datastream. Our sample contains 268,400 bond-day observations based on 266 bond issues from 114 unique firms. Our sample covers the fiscal years 1994 to $2005 .^{8}$

\section{B. Variable Descriptions}

\section{B.1. Debt Maturity Regression}

\section{B.1.1. Dependent Variables: Debt Maturity Structure}

We use two measures for debt maturity structure. Our first variable, ST3, measures the proportion of total debt maturing in three years or less. Alternatively, we measure the maturity 
structure of debt as the proportion of debt maturing in five years or less (denoted by ST5). ${ }^{9}$ These two measures are consistent with prior literature. ${ }^{10}$

\section{B.1.2. Treatment Variables: CEO Portfolio Sensitivities}

We define the CEO's portfolio price sensitivity (PRCSEN) as the change in the value of the CEO's stock and option portfolio in response to a $1 \%$ increase in the price of the firm's common stock. Volatility sensitivity (VOLSEN) is similarly defined as the change in the value of the CEO's option portfolio due to a $1 \%$ increase in the annualized standard deviation of the

firm's stock return. ${ }^{11}$ Partial derivatives of the option price with respect to stock price (delta) and stock return volatility (vega) are based on the Black-Scholes (1973) option pricing model adjusted for dividends by Merton (1973). We follow Guay (1999) and Core and Guay (2002) in calculating vega and delta, consistent with recent papers including Yermack (1995), Hall and Liebman (1998), Aggarwal and Samwick (2006), Core and Guay (2002), Guay (1999), Cohen, Hall, and Viceira (2000), Datta, Iskandar-Datta, and Raman (2005), and Rajgopal and Shevlin (2002). We discuss the derivation of delta and vega in more detail in Appendix A.

\section{B.1.3. Control Variables}

We choose the control variables based on previous debt maturity literature. Earlier studies analyze the relation between debt maturity and firm size (LSIZE - in logs), the square of firm size (LSIZE2), leverage (LEVERAGE), asset maturity (ASSET_MAT), managerial ownership $(O W N)$, market-to-book $(M / B)$, term structure of interest rates (TERM), abnormal earnings $(A B N E A R N)$, asset return standard deviations (STD_DEV), and dummy variables for firms with S\&P credit ratings (RATE_DUM), firms with a high Altman (1977) Z-score (ZSCORE_DUM), and firms from regulated industries $\left(R E G_{-} D U M\right)$. We provide more detailed definitions and data sources for all variables in the maturity regression in Appendix B. We also provide motivations 
for each of the right-hand-side variables in a supplemental Internet Appendix, available online at the Journal of Finance website (http://www.afajof.org/supplements.asp).

\section{B.1.4. Sample Distribution and Summary Statistics}

We estimate the maturity regression based on the debt maturity sample. We present the debt maturity sample distribution in Table I. The full sample includes 6,825 observations over the 1992 to 2005 period. Panel A presents the time series distribution of ST3 (proportion of total debt maturing in three years or less), ST5 (proportion of total debt maturing in five years or less), LEVERAGE (long-term debt divided by total assets), PRCSEN (change in value of CEO's portfolio due to a $1 \%$ increase in stock price), and VOLSEN (change in value of CEO's portfolio due to a $1 \%$ increase in stock return volatility); Panel B presents the cross-sectional distributions of the same variables by industry. The industry breakdown is based on two-digit SIC codes.

\section{[Insert Table I]}

Our debt maturity measures (including ST3 and ST5) and LEVERAGE have remained relatively stable over the course of our sample period (Panel A). There is an upward trend in the use of short-term debt from 1992 until 2000, followed by a general decline. Both ST3 and ST5 reach their highest median values of $43.2 \%$ and $66.6 \%$, respectively, at the top of the bull market in 2000. ST3 obtains its lowest median value of $28.5 \%$ in 2005 , while ST5 obtains its lowest median value of $46.6 \%$ in 1992 .

In contrast to the gradual rise and fall of short-term debt usage over our sample period, CEO sensitivities display a strong secular trend. The median sensitivity of CEO portfolios to a $1 \%$ increase in stock price (PRCSEN) increases from 1.111 in 1992 to 2.960 in 2005 . This result suggests that compensation committees have strengthened the connection between CEO wealth and shareholder value. As described in our hypothesis development section, an increase in 
PRCSEN is expected to reduce the CEO's appetite for risk (all else equal). The median sensitivity of CEO portfolios to a $1 \%$ increase in stock return volatility (VOLSEN) rises from 0.109 in 1992 to 0.748 in 2005. An increase in VOLSEN is expected to increase the CEO's appetite for risk (all else equal), exacerbating conflicts of interest between owners and creditors.

Panel B exhibits the cross-sectional variation (by industry) in short-term debt usage and portfolio sensitivities. The number of firms in each industry ranges from a low of five (tobacco products industry) to a high of 883 (electric, gas, and sanitary services industry). There is considerable variation in the use of short-term debt across these industrial categories.

In Table II, we present summary statistics for our dependent and right-hand-side variables in the maturity regression. The dependent variable $S T 3$ has a mean value of $39.8 \%$, which is similar to the reported mean of $40 \%$ in Table 1 of Datta, Iskandar-Datta, and Raman (2005). The second dependent variable, ST5, has a mean value of $58.3 \%$. Turning to the treatment variables, PRCSEN has a mean of 6.914 and VOLSEN has a mean of 1.108. Because the distributions of PRCSEN and VOLSEN are right-skewed, we use natural logarithm transformations in our empirical tests. ${ }^{12}$ The statistics for both treatment variables are similar to those reported in Table 1 of Coles, Daniel, and Naveen (2006). The summary statistics for our control variables are consistent with those reported in Johnson (2003), Datta, Iskandar-Datta, and Raman (2005), and Billet, King, and Mauer (2007), among others.

\section{[Insert Table II]}

\section{B.2. Cost of Debt Regression}

\section{B.2.1. Dependent Variable: Cost of Debt}

In our cost of debt regression, we use the yield spread (SPREAD) measured as the daily difference between the corporate bond's daily yield-to-maturity and the linearly interpolated 
benchmark Treasury bond yield (BENCHMARK_TREAS) as our dependent variable. Benchmark Treasury yields are based on 1,2,3, 5, 7, 10, 20, and 30-year constant maturity series. ${ }^{13}$

\section{B.2.2. Treatment and Control Variables}

Our main variables of interest are the interaction terms between managerial incentives (LPRCSEN and LVOLSEN) and maturity (LMAT). We define LMAT as the natural logarithm of the bond's maturity, in years. We match the previous fiscal year's information for all treatment and control variables with current bond spreads to ensure that the CEO's portfolio sensitivities (as well as the accounting information) are known by the bond market at the time that borrowing costs are determined.

We also control for several variables that have been shown by previous literature to influence yield spreads at both the firm level and the aggregate level. Specifically, we control for stock volatility (STD_RET), stock return $\left(A V G \_R E T\right)$, bond rating $(R A T I N G)$, profitability $(R O S$, or return on sales), leverage (LEVERAGE), interest coverage (INTCOVERAGE), coupon rate (COUPON), bond illiquidity (ILLIQUIDITY), bond issue size (ISSUE_SIZE), Treasury rate (BENCHMARK_TREAS), yield curve slope (YLDCRV_SLOPE), and the Eurodollar-Treasury spread (EURO_TREAS_SPREAD). We provide more detailed definitions and data sources for all variables in the cost of debt regression in Appendix B, and we discuss the motivation for each of the right-hand-side variables in the supplemental Internet Appendix.

\section{B.2.3. Sample Distribution and Summary Statistics}

Table III reports summary statistics for the variables used in the cost of debt regression based on the bond yield sample. Panel A shows generally increasing yield spreads across each risk category, moving from AAA-rated bonds in the far left column to CCC-rated bonds in the

far right column. ${ }^{14} \mathrm{We}$ find monotonically increasing yield spreads within each risk category, 
moving from short-term to long-term maturities. In Panel B, we present means and standard deviations, as well as variable values at the minimum, maximum, $5^{\text {th }}, 25^{\text {th }}, 50^{\text {th }}, 75^{\text {th }}$, and $95^{\text {th }}$ percentiles. We find considerable variation for the dependent variable, SPREAD, as well as for the independent variables. Bond maturity $(M A T)$, for example, ranges from 7.718 years at the $25^{\text {th }}$ percentile to 21.182 years at the $75^{\text {th }}$ percentile.

\section{[Insert Table III]}

\section{III.Estimation Methods and Empirical Results}

\section{A. Debt Maturity Regression}

\section{A.1. Pooled Cross-Sectional, Time-Series Analysis}

We estimate the following pooled cross-sectional, times-series regression using the debt maturity sample as follows:

$$
\begin{aligned}
& \operatorname{ST3}_{i, t}\left(\operatorname{ST5}_{i, t}\right)=\alpha_{0}+\alpha_{1} \operatorname{LPRCSEN}_{i, t}+\alpha_{2} \operatorname{LVOLSEN}_{i, t}+\alpha_{3} \operatorname{LSIZE}_{i, t}+\alpha_{4} \operatorname{LSIZE}_{i, t}+ \\
& \alpha_{5} L E V E R A G E_{i, t}+\alpha_{6} A S S E T_{-} M A T_{i, t}+\alpha_{7} O W N_{i, t}+\alpha_{8} M / B_{i, t}+\alpha_{9} T_{E R M_{i, t}}+ \\
& \alpha_{10} R E G \_D U M_{i, t}+\alpha_{11} A B N E \bar{A} R N_{i, t}+\alpha_{12} S T D \_R E T_{i, t}+\alpha_{13} R A T E \_D U M_{i, t}+ \\
& \alpha_{14} Z S C O R E \_D U M_{i, t}+\varepsilon_{i, t} \text {, }
\end{aligned}
$$

where all variables are defined in Appendix B.

In Table IV, we report the empirical results from pooled regression model (1). We use Rogers (1993) industry-year clustered standard errors in assessing statistical significance. According to hypothesis H1a, we expect a negative relation between the use of short-term debt (ST3) and the CEO's portfolio sensitivity to stock prices (LPRCSEN). Our regression results support this hypothesis by showing that LPRCSEN's estimated coefficient (-0.0385) is negative and highly significant. According to $\mathrm{H} 1 \mathrm{~b}$, we expect a positive relation between the use of shortterm debt (ST3) and the CEO's portfolio sensitivity to stock return volatility (LVOLSEN). Again, the regression results support this hypothesis by showing that LVOLSEN's estimated coefficient (0.0309) is positive and highly significant. 


\section{[Insert Table IV]}

Using ST5 as the dependent variable, we find that the estimated coefficient on LPRCSEN $(-0.0179)$ is negative and significant. This finding suggests that longer-term maturities are more likely to be chosen when managers' incentives are aligned with creditors. We also find that the estimated coefficient on LVOLSEN (0.0277) is positive and significant.

Following Datta, Iskandar-Datta, and Raman (2005), we also estimate a firm fixed-effects model. The results, which are reported in the supplemental Internet Appendix, ${ }^{15}$ are similar to those reported in Table IV. Specifically, the LPRCSEN coefficients are negative and statistically significant, and the LVOLSEN coefficients are positive and statistically significant. Taken together, the evidence shows that when the ex ante incentive of managers to substitute risky assets for safe assets is high (i.e., high portfolio vegas), short maturity debt is more likely to be chosen to mitigate bondholder-shareholder agency conflicts. ${ }^{16}$

Besides the main variables of interest, LPRCSEN and LVOLSEN, our Table IV pooled regressions also yield consistent results for the control variables. Most of the control variables are statistically significant and display the expected sign based on previous studies (e.g., Datta, Iskandar-Datta, and Raman (2005)). Specifically, the estimated coefficients on LSIZE, LEVERAGE, ASSET_MAT, REG_DUM (ST5 regression only), RATE_DUM, and ZSCORE_DUM are negative and statistically significant, consistent with expectations and previous findings. The estimated coefficients on LSIZE2, OWN, and STD_RET (ST5 regression only) are positive and significant, also consistent with expectations and previous findings. We obtain insignificant results for $M / B, T E R M, R E G \_D U M$ (ST3 regression only), ABNEARN, and STD_RET (ST3 regression only). Overall, our pooled regression results explain between $22.6 \%$ and $25.1 \%$ of the variation in short-term debt. 
We also evaluate the economic significance of our findings. Our Table IV slope estimates on LPRCSEN and LVOLSEN are -0.0385 and 0.0309 , respectively. When price sensitivity changes from the $50^{\text {th }}$ percentile to the $95^{\text {th }}$ percentile, the firm's use of short-term debt (ST3) decreases by $8.7 \%$. Thus, for a firm with roughly $40 \%$ of its total debt in short-term maturities (the sample mean in Table II), a change in $L P R C S E N$ from the $50^{\text {th }}$ to the $95^{\text {th }}$ percentile would reduce this firm's short-term component from $40 \%$ to $31.3 \%$ of total firm debt. The same computation for LVOLSEN shows an increase of $4.4 \%$ in the firm's use of short-term debt (ST3), implying an increase in the short-term component from $40 \%$ to $44.4 \%$ of total firm debt. ${ }^{17} \mathrm{We}$ conclude that there is an economically significant relation between portfolio sensitivities and the maturity structure of corporate debt.

\section{A.2. Generalized Method of Moments (GMM) Estimation}

If debt maturity and leverage are jointly determined, then ordinary least squares estimation can lead to a biased leverage coefficient. To address this concern, in this section we estimate a system that models leverage and debt maturity as jointly endogenous. Our twoequation system is specified as follows:

$$
\begin{aligned}
& \operatorname{LEVERAGE}_{i, t}=\beta_{0}+\beta_{1} \operatorname{ST3}_{i, t}\left(\operatorname{STS}_{i, t}\right)+\beta_{2} \operatorname{LPRCSEN}_{i, t}+\beta_{3} \operatorname{LVOLSEN}_{i, t}+\beta_{4} \operatorname{LSIZE}_{i, t}+ \\
& \beta_{5} O W N_{i, t}+\beta_{6} M / B_{i, t}+\beta_{7} R E G_{-} D U M_{i, t}+\beta_{8} A B N E A R N_{i, t}+\beta_{9} S T D_{-} R E T_{i, t}+ \\
& \beta_{10} F I X_{-} A S S E T_{i, t}+\beta_{11} R O A_{i, t}+\beta_{12} N O L \_D U M_{i, t}+\beta_{13} I T C \_D U M_{i, t}+\zeta_{i, t} \\
& \operatorname{ST3}_{i, t}\left(\operatorname{ST5}_{i, t}\right)=\alpha_{0}+\alpha_{1} \operatorname{LPRCSEN}_{i, t}+\alpha_{2} \operatorname{LVOLSEN}_{i, t}+\alpha_{3} \operatorname{LSIZE}_{i, t}+\alpha_{4} \operatorname{LSIZE2}_{i, t}+ \\
& \alpha_{5} L E V E R A G E_{i, t}+\alpha_{6} A S S E T{ }_{2} M A T_{i, t}+\alpha_{7} O W N_{i, t}+\alpha_{8} M / B_{i, t}+\alpha_{9} \text { TERM }_{i, t}+ \\
& \alpha_{10} R E G_{-} D U M_{i, t}+\alpha_{11} A B N E A R N_{i, t}+\alpha_{12} S T D \_R E T_{i, t}+\alpha_{13} R A T E \_D U M_{i, t}+ \\
& \alpha_{14} Z S C O R E_{-} D U M_{i, t}+\varepsilon_{i, t},
\end{aligned}
$$

where dependent and right-hand-side variables are as defined in Appendix B.

We rely on earlier theoretical studies to guide our selection of right-hand-side variables in our simultaneous equations. Theoretical capital structure studies show that the fixed asset ratio (FIX_ASSET), profitability measure (ROA), and expected marginal tax rate (NOL_DUM and 
ITC_DUM) are important determinants of leverage (see Johnson (2003), Barclay, Marx, and Smith (2003)). In contrast, theoretical debt maturity studies do not find that fixed asset ratios (when asset maturity is controlled for), profitability measures, or the expected marginal tax rate are important determinants of maturity. We therefore assume that these variables are orthogonal to the error term and restrict their coefficients to be zero in the maturity equation. ${ }^{18}$ Further, theoretical capital structure studies make no claims about the square of firm size (LSIZE2), asset maturity (ASSET_MAT), term structure (TERM), the rated-firm dummy (RATE_DUM), or financial distress $($ ZSCORE_DUM $) .{ }^{19}$ We therefore treat these variables as orthogonal to the error term and restrict their coefficients to be zero in the leverage equation. ${ }^{20}$

Table $\mathrm{V}$ reports the empirical results for the maturity equation (3). The results support our H1a, with a negative (-0.0829) and significant coefficient on LPRCSEN. The empirical results also support our H1b, with a positive (0.0984) and significant coefficient on LVOLSEN. We obtain similar results when we extend our definition of short-term debt from three years to five years. Using ST5 as the dependent variable, we find a negative (-0.0698) and significant coefficient on LPRCSEN, and a positive (0.1269) and significant coefficient on LVOLSEN. Overall, these GMM results confirm the earlier pooled regression results and show that debt maturity structure can reduce the agency costs of debt. ${ }^{21}$

\section{[Insert Table V]}

\section{A.3. Change-in-Variables Analysis}

We investigate the robustness of the results above with respect to variable changes, as opposed to variable levels. ${ }^{22}$ We estimate the following pooled regression using 5,513 firm-year observations:

$$
\begin{gathered}
\Delta S T 3_{i, t}\left(\Delta S T 5_{i, t}\right)=\alpha_{0}+\alpha_{1} \Delta L P R C S E N_{i, t}+\alpha_{2} \Delta \operatorname{LVOLSEN}_{i, t}+\alpha_{3} \Delta \operatorname{LSIZE}_{i, t}+\alpha_{4} \Delta \operatorname{LSIZE2}_{i, t}+ \\
\alpha_{5} \Delta L E V E R A G E_{i, t}+\alpha_{6} \Delta A S S E T \_M A T_{i, t}+\alpha_{7} \Delta O W N_{i, t}+\alpha_{8} \Delta M / B_{i, t}+\alpha_{9} \Delta T E R M_{i, t}+
\end{gathered}
$$




$$
\alpha_{10} \triangle A B N E A R N_{i, t}+\alpha_{11} \Delta S T D_{-} R E T_{i, t}+\alpha_{12} \Delta R A T E_{-} D U M_{i, t}+\alpha_{13} \Delta Z S C O R E_{-} D U M_{i, t}+\varepsilon_{i, t},
$$

where all variables are as defined previously. Taking first differences $(\Delta)$ reduces our sample size from 6,825 to 5,513 observations. We use the variable's value at $t-2$ if the value at $t-1$ is missing. We also eliminate $R E G \_D U M$ from the change-in-variables specification since it does not change for any firm in our sample. The remaining right-hand-side variables (after taking first differences) are described in Appendix B.

In Table VI, we report the empirical results from pooled regression model (4). The results support our H1a with a negative (-0.0440) and significant coefficient on $\triangle L P R C S E N$; the results also support our H1b by finding a positive (0.0483) and significant coefficient for $\triangle L V O L S E N$. We obtain similar results for changes in short-term debt with maturities up to five years. Using $\triangle S T 5$ as the dependent variable, we find a negative (positive) and significant coefficient on $\triangle L P R C S E N(\triangle L V O L S E N)$. Overall, these change-in-variables results confirm the earlier findings based on variable levels.

\section{[Insert Table VI]}

\section{A.4. Managerial Incentives, Investment Policy, and Capital Structure}

Coles, Daniel, and Naveen (2006) argue that it is important to disentangle the effects of managerial compensation incentives on the firm's investment and financing policies from the effects of these policies (and the corresponding risk profile of the firm's assets) on managerial compensation incentives. Accordingly, we follow Coles, Daniel, and Naveen's (2006) framework and examine the relations among a firm's managerial incentives (LPRCSEN and LVOLSEN), financial policies (ST3, ST5, and LEVERAGE), and investment policies (i.e., research and development expenditures $(\mathrm{RD})$ and net capital expenditures $(C A P E X))$. 
In Panel A of Table VII, we report our results for the dependent variables ST3, LPRCSEN, LVOLSEN, LEVERAGE, RD, CAPEX based on GMM estimation. In Panel B, we use the alternative definition for short-term debt, ST5, in place of ST3. Our right-hand-side variables include the variables described above and in Appendix B, augmented by additional variables motivated by prior literature (e.g., Coles, Daniel, and Naveen (2006)) ${ }^{23}$ The additional righthand-side variables include the following: LTENURE, the logarithmic transformation of the CEO's tenure measured in years; SURCASH, the cash from assets-in-place; EQUITY_RISK, the logarithmic transformation of monthly stock return variance during the fiscal year; CASHCOMP, the sum of the CEO's salary and bonus (in 100 thousands); SGR, the sales growth rate; and STOCKRET, the buy-and-hold return during the fiscal year. We provide more detailed definitions and data sources in Appendix B.

As Barclay, Marx, and Smith (2003) note, it becomes increasingly difficult to find identifying independent variables for increasing numbers of structural equations. In spite of this difficulty, we continue to follow previous theoretical studies to guide our choice of structural restrictions and help identify our six-equation system. Previous theory shows that firm size and the investment opportunity set are important determinants of a firm's financial, investment, and compensation policies. We therefore view firm size (LSIZE) and market-to-book $(M / B)$ as exogenous or pre-determined and include them in all six equations. To the best of our knowledge, previous theory does not posit significant relations between our other instruments (in the debt maturity and leverage regressions) and compensation incentives (LPRCSEN and LVOLSEN) or investment policies ( $R D$ and CAPEX). We therefore treat these variables as orthogonal to the error terms in the compensation and investment equations. We note, however, that if these assumptions are violated, then our estimation procedure can lead to biased estimates. 
The results in the first column of Panel A support our main hypotheses. ${ }^{24}$ We find that the estimated coefficient on LPRCSEN is negative (-0.1560) and significant, and the estimated coefficient on LVOLSEN is positive (0.1904) and significant. In column 4, we examine the relation between managerial incentives and financing policies. We find that the manager's use of leverage is negatively $(-0.3495)$ related to delta and positively $(0.0720)$ related to vega. Both coefficients are significant. These findings are consistent with Coles, Daniel, and Naveen (2006), who show that managers with high vega seek risky financing policies. The results in column 4 also show that the relation between short-term debt and leverage is negative $(-0.3495)$ and significant.

In columns 5 and 6 , we examine the relation between managerial incentives and investing policies. We focus on the vega dimension of managerial incentives since Coles, Daniel, and Naveen (2006) hypothesize a positive (negative) relation between LVOLSEN and RD (CAPEX); in contrast, their predictions on $L P R C S E N$ and $R D(C A P E X)$ are ambiguous. All else equal, higher LVOLSEN should encourage high risk investments in R\&D expenditures and discourage low-risk investments in fixed-asset capital expenditures. Our results support these hypotheses. Estimated coefficients on LVOLSEN are positive (0.0393) and significant in the RD equation, and negative (-0.0462) and significant in the CAPEX equation. More importantly, the results in Panel A suggest that even after controlling for the simultaneity between managerial compensation incentives and a firm's investment and financing policies, our main results continue to hold: short-maturity debt increases in vega but decreases in delta. ${ }^{25,26}$

\section{[Insert Table VII]}

\section{A.5. New Debt Issues}


Our previous results focus on the relation between CEO portfolio sensitivities and current maturity structures of debt. In this section, we examine the relation between portfolio sensitivities and the maturity of new debt issues - an incremental approach. ${ }^{27}$ This setting allows us to take the perspective of a prospective creditor who analyzes the firm characteristics that will determine the maturity structure of new lending. Consistent with our central hypothesis, we expect that short-maturity debt is more (less) likely to be used when LVOLSEN (LPRCSEN) is high.

We obtain the maturity structure of new debt issues from the Securities Data Company (SDC). Our sample includes 7,388 issues representing 873 unique firms over the period 1992 to $2005 .^{28} \mathrm{We}$ also construct two alternative samples that consolidate the original sample into a firm-year format by treating multiple issues throughout the year as a single issue. In the first consolidated sample, maturity is computed using an issue size-weighted average maturity for firms with multiple issues; in the second consolidated sample, maturity is computed using an equal-weighted average maturity for firms with multiple issues. The consolidated samples include 3,122 firm-year observations.

We present pooled regression results for each of our three samples in Table VIII. For the unconsolidated sample, the dependent variable is the natural logarithm of the maturity of the new debt issues $(L M A T)$. In the consolidated samples, the dependent variable is the natural logarithm of the issue size-weighted maturity, LWEIGHT_AVG_MAT, or the natural logarithm of the equal-weighted maturity, $L A V G_{-} M A T$. As hypothesized, the estimated coefficients on LPRCSEN are positive and significant across all three regressions, and the estimated coefficients on LVOLSEN are negative and significant across all three regressions. Similar to previous results, 
we find that the CEO's portfolio sensitivities influence the maturity choice of new debt issues.

The coefficients on the control variables are consistent with prior literature.

\section{[Insert Table VIII]}

\section{B. Cost of Debt Regression}

We test $\mathrm{H} 2$ by estimating the following system of simultaneous equations, which allows for the joint determination of yield spreads and debt maturity: ${ }^{29}$

$$
\begin{aligned}
& \operatorname{SPREAD}_{i, j, t, d}=\beta_{0}+\beta_{1} \operatorname{LMAT}_{i, j, t, d}+\beta_{2} \operatorname{LPRCSEN}_{i, t-1}+\beta_{3} \operatorname{LVOLSEN}_{i, t-1}+ \\
& \left(\beta_{4} L P R C S E N_{i, t-1} x L M A T_{i, j, t, d}+\beta_{5} L V O L S E N_{i, t-1} x L M A T_{i, j, t, d}\right)+ \\
& \beta_{6} S T D \_R E T_{i, t, d-1}+\beta_{7} A V G_{-} R E T_{i, t, d-1}+\beta_{8} R A T I N G_{i, j, t, d-1}+\beta_{9} R O S_{i, t-1}+ \\
& \beta_{10} L E V E R A G E_{i, t-1}+\beta_{11} I_{1 N T C O V E R A G E} E_{i, t-1}+\beta_{12} \text { COUPON }_{i, j}+ \\
& \beta_{13} I_{L L I Q U I D I T Y}{ }_{i, j, t, d-1}+\beta_{14} I S S U E \_S I Z E_{i, j}+\beta_{15} B E N C H M A R K_{-} T R E A S_{i, j, t, d}+ \\
& \beta_{16} Y L D C R V \_S L O P E_{t, d}+\beta_{17} E U R O \_T R E A S \_S P R E A D_{t, d}+i \text { issuer fixed effects }+\zeta_{i, j, t, d} \\
& \operatorname{LMAT}_{i, j, t, d}=\alpha_{0}+\alpha_{1} \operatorname{SPREAD}_{i, j, t, d}+\alpha_{2} \operatorname{LPRCSEN}_{i, t-1}+\alpha_{3} \operatorname{LVOLSEN}_{i, t-1}+\alpha_{4} \operatorname{STD}_{-} R E T_{i, t, d-1}+ \\
& \alpha_{5} L_{E V E R A G E} E_{i, t-1}+\alpha_{6} Y L D C R V \_S L O P E_{t, d}+\alpha_{7} L S I Z E_{i, t-1}+\alpha_{8} L S I Z E 2_{i, t-1}+ \\
& \alpha_{9} A S S E T \_M A T_{i, t-1}+\alpha_{10} O W N_{i, t-1}+\alpha_{11} M / B_{i, t-1}+\alpha_{12} A B N E A R N_{i, t-1}+ \\
& \alpha_{12} \text { ZSCORE_DUM } M_{i, t-1}+\text { issuer fixed effects }+\varepsilon_{i, j, t, d} \text {, }
\end{aligned}
$$

where $i, j, t$, and $d$ denote the $i^{\text {th }}$ firm and $j^{\text {th }}$ bond for year $t$ and day $d .{ }^{30}$ Our main variables of interest are the interaction terms LPRCSEN x LMAT and LVOLSEN x LMAT. All other variables are as defined in Appendix B.

Since an endogenous variable $(L M A T)$ is interacted with portfolio sensitivities we use nonlinear GMM. ${ }^{31}$ Under $\mathrm{H} 2$, we expect $\beta_{4}$ to be negative and $\beta_{5}$ to be positive. Prior literature documents a positive relation between managerial compensation risk and the cost of debt. We therefore expect $\beta_{2}$ to be negative and $\beta_{3}$ to be positive. The coefficient $\beta_{1}$ captures the maturity premium (i.e., the premium required by creditors for a unit increase in the bond's maturity) and is expected to be positive. ${ }^{32}$

We report our simultaneous equation results in Table IX based on the bond yield sample. ${ }^{33}$ In the spread equation (system 1), the coefficient on $\operatorname{LPRCSEN}(-0.1790)$ is negative 
and significant and the coefficient on LVOLSEN (0.2209) is positive and significant. Both results are consistent with prior studies suggesting that creditors understand the risk incentives imbedded in managerial compensation and rationally price these risks (Daniel, Martin, and Naveen (2004), Billet, King, and Mauer (2007), and Shaw (2007)). ${ }^{34}$ In system 2, we include two interaction terms on LVOLSEN and LPRCSEN with LMAT. Consistent with H2, we find that the coefficient on LVOLSEN x LMAT (0.7847) is positive and significant, and the coefficient on LPRCSEN x LMAT (-1.0830) is negative and significant, suggesting that short-term debt reduces agency cost of debt arising from managerial compensation incentives. In the maturity regression of both systems, we find a positive and significant coefficient on LPRCSEN and a negative and significant coefficient on LVOLSEN. Both of these results are consistent with the evidence reported in Tables IV to VIII.

The combined results in Table IX lead to the conclusion that short-term debt mitigates agency costs of debt arising from managerial compensation incentives. At the same time, the results also indicate that some firms with high compensation risk still use longer-term debt, and consequently they incur a higher cost of debt. Although creditors attempt to steer risk-tolerant managers towards short-term debt, creditors are also willing to issue longer-term debt to risktolerant managers for a commensurate risk premium. Some risk-tolerant managers are willing to incur the risk premium associated with longer-term debt for reasons such as liquidity risk. For example, Diamond $(1991,1993)$ and Sharpe (1991) argue that too much short-maturity debt creates additional risks of suboptimal liquidation. This liquidity (or rollover) risk increases expected bankruptcy costs and reduces equity value. In addition, Leland and Toft (1996) argue that short-term debt can reduce managers' ability to pursue risky investments, and the reduction in such behavior can decrease the option value of managerial compensation. 


\section{[Insert Table IX]}

Our Table IX results also allow us to show how changes in debt maturity affect the partial derivative of credit spreads with respect to LVOLSEN and LPRCSEN. Using our system 2 results, these two partial derivatives are as follows:

$$
\begin{aligned}
& \frac{\partial \text { SPREAD }}{\partial \text { LVOLSEN }}=-1.7985+0.7847 \times \text { LMAT } \\
& \frac{\partial \text { SPREAD }}{\partial \text { LPRCSEN }}=2.5596-1.0830 \times \text { LMAT. }
\end{aligned}
$$

When equation (7) is evaluated at the median LMAT level of 2.722, or 15.2 years, a one-unit increase in LVOLSEN raises credit spreads by $0.3375 \%$. However, when equation (7) is evaluated at LMAT's $95^{\text {th }}$ percentile of 3.257 , or roughly 26 years, then the LVOLSEN effect on credit spreads increases to $0.7573 \%$. This economically significant difference in yield spread sensitivity to LVOLSEN between short- and long-term maturities clearly shows that short-term debt mitigates the agency costs of vega-related incentives.

Similarly, when equation (8) is evaluated at the median LMAT level, we find that a oneunit increase in LPRCSEN reduces credit spreads by $0.3883 \%$, and when equation (8) is evaluated at $L M A T$ 's $95^{\text {th }}$ percentile, a one-unit increase in $L P R C S E N$ reduces credit spreads by $0.9677 \%$. Overall, these results confirm that the maturity structure of corporate debt plays an economically significant role in reducing compensation-related agency costs of debt.

In summary, credit yield premiums are disproportionately lower at short-term maturities for CEOs with risk-seeking compensation packages (i.e., high vega/low delta portfolios). As a result, such firms are more likely to borrow at short-term maturities. This finding is consistent with Berlin's (2006) observation that because financing costs can be prohibitively high for some risky firms, their only viable access to funding lies with short-term debt. 


\section{Conclusion}

Managerial stock and option compensation exerts two opposing forces on managerial risk-seeking behavior. One effect arises from the sensitivity of the manager's portfolio to stock prices (delta), and the other effect arises from the sensitivity to stock return volatility (vega). All else equal, higher sensitivity of the manager's compensation package to stock prices will discourage risk-taking behavior whereas higher sensitivity of the manager's compensation package to stock return volatility will encourage risk-taking behavior (Knopf, Nam, and Thornton (2002)). Creditors understand these incentives and rationally price the compensationinduced risks. Prior research suggests that short-term debt can reduce agency costs associated with asset substitution and improve the efficiency of monitoring by lenders. In this paper, we analyze the role of short-term debt in mitigating agency costs of debt arising from CEO portfolio sensitivities. Our first hypothesis is that short-term debt is positively related to the sensitivity of the CEO's portfolio to stock return volatility (vega), and negatively related to the sensitivity of the CEO's portfolio to stock prices (delta). Our second hypothesis is that the use of short-term debt reduces the positive (negative) relation between vega (delta) and the cost of debt.

To test the first hypothesis, we construct a sample of 6,825 firm-year observations during the 14-year period from 1992 to 2005, use alternative definitions of short-term debt, implement Core and Guay's (2002) method for estimating option sensitivities, and employ several econometric techniques to analyze the predicted relations. We find a consistently negative and statistically significant relation between the compensation package's sensitivity to stock prices and short-term debt. We also find a consistently positive and statistically significant relation between the compensation package's sensitivity to stock return volatility and short-term debt. 
Our empirical findings are robust to controls for numerous factors that have been shown to affect debt maturity. To further mitigate endogeneity concerns, we re-test our main hypotheses using a sample of new debt issues. Our results confirm that creditors are more (less) likely to lend shortterm funds when CEOs have high vega (high delta) incentive packages.

We also examine the relation between managerial incentives, short-maturity debt, and corporate bond yields. Consistent with prior literature, we find that bond yields are increasing in vega and decreasing in delta. More importantly, we analyze the interaction between maturity structure and managerial incentives on bond yields. We show that short-maturity debt attenuates the impact of vega on bond yields while it reinforces the impact of delta on bond yields. These results suggest that short-maturity debt constrains managerial risk preferences and mitigates asset substitution problems.

Overall, this study extends the literature in several areas, including executive compensation, agency costs of debt, and the determinants of debt maturity. We provide new evidence that the two portfolio sensitivities in managerial compensation affect corporate debt maturity, and that they do so in quite different ways. Our results add to the literature on the determinants of debt maturity by showing that executive portfolio deltas and vegas are significant determinants, both statistically and economically. Our study also sheds light on the creditor's assessment of the causal connections between executive compensation and riskseeking behavior on the one hand, and between risk-seeking behavior and agency costs of debt on the other hand. Perhaps most importantly, our empirical results highlight the role of shortterm debt in mitigating agency costs of debt. 


\section{Appendix A: Computation of Portfolio Sensitivities}

We define the CEO's portfolio price sensitivity (PRCSEN) as the change in the value of the CEO's stock and option portfolio due to a $1 \%$ increase in the price of the firm's common stock. Volatility sensitivity (VOLSEN) is defined as the change in the value of the CEO's option portfolio due to a $1 \%$ change in the annualized standard deviation of the firm's stock returns. ${ }^{35}$ Partial derivatives of the option price with respect to stock price (delta) and stock return volatility (vega) are based on the Black-Scholes (1973) option-pricing model adjusted for dividends by Merton (1973) as follows:

$$
\begin{aligned}
& \Delta=e^{-d T} N(Z) \\
& v=e^{-d T} N^{\prime}(Z) S \sqrt{T}
\end{aligned}
$$

$$
Z=\frac{\ln \left[\frac{S}{X}\right]+T\left[r-d+\frac{\sigma^{2}}{2}\right]}{\sigma \sqrt{T}}
$$

where $N$ is the cumulative probability function for the normal distribution; $N$ ' is the density function for the normal distribution; $S$ is the price of the underlying stock; $X$ is the exercise price of the option; $\sigma$ is the expected stock return volatility over the life of the option; $r$ is the natural logarithm of the risk-free interest rate; $T$ is the time to maturity of the option in years; and $d$ is the natural logarithm of the expected dividend yield over the life of the option.

The six variables necessary to compute the delta and vega of an option are the exercise price, time to maturity, volatility, risk-free rate, dividend yield, and stock price. All of these input variables are either directly observable or can be accurately estimated. ${ }^{36}$ Because details on the exercise prices and maturities of CEO options are not fully disclosed in annual statements, we follow Core and Guay's (2002) approximation method. ${ }^{37}$ They show that their method explains $99 \%$ of the actual variation in option portfolio values and sensitivities.

We partition the CEO's option portfolio into three parts: (1) options from new grants, (2) exercisable options from previous grants, and (3) non-exercisable options from previous grants. ExecuComp provides full information on exercise prices (item EXPRIC in ExecuComp) and times to maturity for new grants (item EXDATE in ExecuComp ), which makes the computation of option delta and vega fairly straightforward. However, for previously granted options, no data are available on exercise prices and times to maturity. To estimate the average exercise price for previously granted options, we use the "realizable values" as in Core and Guay (2002). The realizable value is the immediate exercise value of the CEO's options. We divide the realizable value of previously granted options by the number of options to find how much, on average, the stock price is above the exercise price. ${ }^{38}$ Subtracting this figure from the stock price yields the exercise price.

We follow Core and Guay (2002) when estimating times to maturity for previously granted options (unexercisable and exercisable). First, we assume that the time to maturity of an unexercisable option is one year less than that of a new grant. This assumption is consistent with evidence in Kole (1997) that vesting periods are narrowly bounded between 20 and 28 months, with an average of 24 months. Second, we assume that the time to maturity of an exercisable option is three years less than that of an unexercisable option. ${ }^{39}$ Consequently, we set the 
maturity of an unexercisable (exercisable) option to the new grant's maturity minus one (four). If no options are granted in the current year, we set the time to maturity of an exercisable (unexercisable) option to six (nine) years. ${ }^{40}$ Once the delta $(\Delta)$ and vega $(v)$ of each option partition are determined, we calculate PRCSEN and VOLSEN as follows:

$$
\begin{aligned}
& \text { PRCSEN }=\frac{S}{100}\left(\Delta_{N G} N_{N G}+\Delta_{P G E X} N_{P G E X}+\Delta_{P G U N E X} N_{P G U N E X}+N_{\text {STOCK }}\right) \\
& \text { VOLSEN }=\frac{1}{100}\left(v_{N G} N_{N G}+v_{P G E X} N_{P G E X}+v_{P G U N E X} N_{P G U N E X}\right),
\end{aligned}
$$

where $S$ and $N$. denote the stock price and the number of options/stocks in hundreds of thousands. The subscripts $N G, P G E X, P G U N E X$, and STOCK stand for new grants, previouslygranted exercisable options, previously granted non-exercisable options, and stock holdings, respectively. 


\section{Appendix B: Variable Definitions and Data Sources}

\begin{tabular}{|c|c|}
\hline Variable & Definition and Data Source \\
\hline$\overline{A B N E A R N}$ & $\begin{array}{l}\text { (Earnings in year } t+1(\text { Item\#20) - earnings in year } t) /(\text { share } \\
\text { price (Item\#199) x outstanding shares (Item\#54) in year } t) \text {. Data } \\
\text { source: Compustat Annual Industrial file. }\end{array}$ \\
\hline$A S S E T \_M A T$ & $\begin{array}{l}\text { Book value-weighted average of the maturities of property plant } \\
\text { and equipment and current assets, computed as (gross property, } \\
\text { plant, and equipment (Item \#7)/total assets (Item \#6)) * (gross } \\
\text { property, plant, and equipment (Item \#7)/depreciation expense } \\
(\text { Item \#14)) + (current assets (Item \#4)/total assets (Item \#6)) * } \\
(\text { current assets (Item \#4)/cost of goods sold (Item \#41)). Data } \\
\text { source: Compustat Annual Industrial file. }\end{array}$ \\
\hline$A V G \_R E T$ & $\begin{array}{l}\text { Average of daily stock returns over the preceding } 180 \text { days. } \\
\text { Data source: CRSP daily file. }\end{array}$ \\
\hline BENCHMARK_TREAS & $\begin{array}{l}\text { Treasury rate that corresponds most closely to the specific } \\
\text { bond's maturity. Data source: FRED at the Federal Reserve } \\
\text { Bank of St. Louis. }\end{array}$ \\
\hline CAPEX & $\begin{array}{l}\text { Net capital expenditures (Item \#128 - Item \#107) scaled by } \\
\text { assets (Item } \# 6 \text { ). Data source: Compustat Annual Industrial file. }\end{array}$ \\
\hline САSHCOMP & $\begin{array}{l}\text { Sum of the CEO's salary and bonus (in } 100 \text { thousands). Data } \\
\text { source: Standard and Poor's ExecuComp database. }\end{array}$ \\
\hline COUPON & $\begin{array}{l}\text { Coupon rate of specified bond. Data source: Mergent Fixed } \\
\text { Income Securities Database. }\end{array}$ \\
\hline EQUITY_RISK & $\begin{array}{l}\text { Logarithmic transformation of monthly stock return variance } \\
\text { during the fiscal year. Data source: CRSP daily file. }\end{array}$ \\
\hline EURO_TREAS_SPREAD & $\begin{array}{l}\text { Difference between three-month Eurodollar yields and Treasury } \\
\text { rates. Data source: Eurodollar yields are from Thomson's } \\
\text { Datastream database and Treasury rates are from FRED at the } \\
\text { Federal Reserve Bank of St. Louis. }\end{array}$ \\
\hline FIX_ASSET & $\begin{array}{l}\text { Ratio of net property, plant, and equipment (Item \#8) to total } \\
\text { assets (Item \#6). Data source: Compustat Annual Industrial file. }\end{array}$ \\
\hline ILLIQUIDITY & $\begin{array}{l}\text { Proportion of days with zero bond returns over the preceding } \\
180 \text { days. Data source: Thomson's Datastream database. }\end{array}$ \\
\hline INTCOVERAGE & $\begin{array}{l}\text { Logarithmic transformation of pre-tax interest coverage ratio } \\
(\ln (1+[\text { Item } \# 178+\text { Item \#15]/Item \#15)). Data source: } \\
\text { Compustat Annual Industrial file. }\end{array}$ \\
\hline ISSUE_SIZE & $\begin{array}{l}\text { Natural logarithm of the face value of the bond (in \$millions). } \\
\text { Data source: Mergent Fixed Income Securities Database. }\end{array}$ \\
\hline$I T C \_D U M$ & $\begin{array}{l}\text { Equals one if the firm has an investment tax credit (Item \#51), } \\
\text { and zero otherwise. Data source: Compustat Annual Industrial } \\
\text { file. }\end{array}$ \\
\hline$L A V G \_M A T$ & $\begin{array}{l}\text { Natural logarithm of the equal-weighted maturity. Data source: } \\
\text { Thomson's SDC database. }\end{array}$ \\
\hline LEVERAGE & $\begin{array}{l}\text { Long-term debt (Item \#9) divided by the market value of the } \\
\text { firm. Data source: Compustat Annual Industrial file. }\end{array}$ \\
\hline
\end{tabular}




\author{
LMAT \\ LSIZE \\ LSIZE2 \\ LTENURE \\ LWEIGHT_AVG_MAT \\ $M / B$ \\ NOL_DUM \\ $O W N$
}

PRCSEN

LPRCSEN

RATE_DUM

RATING

$R D$

$R E G \_D U M$

$R O A$

ROS

$S G R$
Natural logarithm of the bond's maturity, in years. Data source: Thomson's SDC database (Table VIII) and Mergent Fixed Income Securities Database (Table IX).

Market value of equity (Item \#199* Item \#54) plus the book value of total assets (Item \#6) minus the book value of equity (Item \#60), in logs. Data source: Compustat Annual Industrial file.

Square of LSIZE.

Logarithmic transformation of the CEO's tenure measured in years. Data source: Standard and Poor's ExecuComp database.

Natural logarithm of the issue size-weighted maturity. Data source: Thomson's SDC database.

Market value of the firm (Item \#199* Item \#54 + Item \#6 Item \#60) divided by the book value of total assets (Item \#6). Data source: Compustat Annual Industrial file.

Equals one if the firm has operating loss carryforwards (Item \#52), and zero otherwise. Data source: Compustat Annual Industrial file.

Number of shares owned by the CEO (SHROWN in ExecuComp) scaled by total shares outstanding (SHRSOUT in ExecuComp). Data source: Standard and Poor's ExecuComp database.

Change in the value of the CEO's stock and option portfolio due to a $1 \%$ increase in the value of the firm's common stock price. Data source: Standard and Poor's ExecuComp database.

Natural logarithm of PRCSEN.

Equals one if a firm has an S\&P rating on long term debt (Item \#280), and zero otherwise. Data source: Compustat Annual Industrial file.

Number between 1 and 19 (e.g., 1 for CCC- and 19 for AAA). We use the average of Standard and Poor's and Moody's ratings. If only one agency has an outstanding rating for a particular bond, we use that agency's rating. Data source: Mergent Fixed Income Securities Database.

Research and development expenditures (Item \#46 or zero if missing) scaled by assets (Item \#6). Data source: Compustat Annual Industrial file.

Equals one if the firm's SIC code is between 4900 and 4939 and zero otherwise. Data source: Compustat Annual Industrial file.

Ratio of operating income before depreciation (Item \#13) to total assets (Item \#6). Data source: Compustat Annual Industrial file.

Operating income before depreciation (Item \#13) scaled by sales (Item \#12). Data source: Compustat Annual Industrial file. Sales growth rate computed as $\ln \left(\right.$ Item $\# 12_{t} /$ Item $\left.\# 12_{t-1}\right)$. Data source: Compustat Annual Industrial file. 
SPREAD

STD_RET

STOCKRET

ST3

ST5

SURCASH

TERM

VOLSEN

LVOLSEN

YLDCRV_SLOPE

ZSCORE_DUM
Daily difference between the corporate bond's daily yield-to maturity and the linearly interpolated benchmark Treasury bond yield (BENCHMARK_TREAS) as our dependent variable. These yields are based on $\overline{1}, 2,3,5,7,10,20$ and 30 year constant maturity series. Data source: Yields are from Thomson's Datastream database and Treasury rates are from the FRED at Federal Reserve Bank of St. Louis.

Monthly stock return standard deviation during the fiscal year multiplied by the ratio of the market value of equity (Item \#199 * Item \#54) to the market value of assets (Item \#199* Item \#54 + Item \#6 - Item \#60). Data source: Monthly returns are from CRSP monthly file and financial accounting information is from Compustat Annual Industrial file.

Buy-and-hold return during the fiscal year. Data source: CRSP monthly file.

Debt in current liabilities (Item \#34) plus debt maturing in the second year (Item \#91) plus debt maturing in the third year (Item \#92), scaled by total debt. Total debt is defined as debt in current liabilities (Iten\#34) plus long-term debt (Item \#9). Data source: Compustat Annual Industrial file.

Debt in current liabilities (Item \#34) plus debt maturing in the second (Item \#91), third (Item \#92), fourth (Item \#93), and fifth years (Item \#94), all scaled by total debt as defined above. Data source: Compustat Annual Industrial file.

Cash from assets-in-place (Item \#308 - Item \#125 + Item \#46) scaled by assets (Item \#6). Data source: Compustat Annual Industrial file.

Yield on 10-year government bonds subtracted from the yield on six-month government bonds at the fiscal yearend. Data source: FRED at the Federal Reserve Bank of St. Louis.

Change in the value of the CEO's option portfolio due to a $1 \%$ change in the annualized standard deviation of stock returns. Data source: Standard and Poor's ExecuComp database.

Natural logarithm of VOLSEN.

Difference between 10-year and two-year Treasury rates. Data source: FRED at the Federal Reserve Bank of St. Louis.

Equals one if Altman's Z-score is greater than 1.81, and zero otherwise. Altman's Z-score is computed as 3.3*Item \#178/Item $\# 6+1.2 *$ (Item \#4-Item \#5)/Item \#6 + Item \#12 /Item\# $6+$ $0.6 *$ Item \#199*Item \#25 / (Item \#9+Item \#34) + 1.4*Item \#36/Item \#6. Data source: Compustat Annual Industrial file. 


\section{References}

Aggarwal, Rajesh K., and Andrew A. Samwick, 2006, Empire-builders and shirkers: Investment, firm performance, and managerial incentives, Journal of Corporate Finance 12, 489-515.

Altman, Edward I., 1977, The Z-score Bankruptcy Model: Past, Present and Future, Financial Crises (Wiley-Interscience, New York).

Angrist, Joshua D., and Alan B. Krueger, 2001, Instrumental variables and the search for identification: From supply and demand to natural experiments, Journal of Economic Perspectives 15, 69-85.

Angrist, Joshua D., and Jorn-Steffen Pischke, 2009, Mostly Harmless Econometrics (Princeton University Press, New Jersey).

Barclay, Michael J., Leslie M. Marx, and Cliff W. Smith, 2003, The joint determination of leverage and maturity, Journal of Corporate Finance 9, 149-167.

Barclay, Michael J., and Cliff W. Smith, 1995, The maturity structure of corporate debt, Journal of Finance 50, 609-631.

Barnea, Amir, Robert A. Haugen, and Lemma W. Senbet, 1980, A rationale for debt maturity structure and call provisions in the agency theoretic framework, Journal of Finance 35, 1223-1234.

Berger, Philip G., Eli Ofek, and David L. Yermack, 1997, Managerial entrenchment and capital structure, Journal of Finance 52, 1411-1438.

Bergstresser, Daniel, and Thomas Philippon, 2006, CEO incentives and earnings management, Journal of Financial Economics 80, 511-529.

Berlin, Mitchell, 2006, Debt maturity: What do economists say? What do CFOs say? Business Review Q1, 3-10.

Billett, Matthew, Tao-Hsien Dolly King, and David C. Mauer, 2007, Growth opportunities and the choice of leverage, debt maturity, and covenants, Journal of Finance 62, 697-730.

Billett, Matthew, David C. Mauer, and Yilei Zhang, 2009, Stockholder and bondholder wealth effects of CEO incentive grants, forthcoming at Financial Management.

Black, Fischer, and Myron S. Scholes, 1973, The pricing of options and corporate liabilities, Journal of Political Economy 81, 637-654.

Burns, Natasha, and Simi Kedia, 2006, The impact of performance-based compensation on misreporting, Journal of Financial Economics, 35-67. 
Carpenter, Jennifer N., 2000, Does option compensation increase managerial risk appetite? Journal of Finance 55, 2311-2331.

Chen, Long, David A. Lesmond, and Jason Wei, 2007, Corporate yield spreads and bond liquidity, Journal of Finance 62, 119-149.

Cheng, Qiang, and Terry Warfield, 2005, Equity incentives and earnings management, The Accounting Review 80, 441-476.

Cohen, Randolph B., Brian J. Hall, and Luis M. Viceira, 2000, Do executive stock options encourage risk-taking? Working paper, Harvard Business School.

Coles, Jeffrey L., Naveen D. Daniel, and Lalitha Naveen, 2006, Managerial incentives and risk taking, Journal of Financial Economics 79, 431-468.

Core, John E., and Wayne R. Guay, 2002, Estimating the value of employee stock option portfolios and their sensitivities to price and volatility, Journal of Accounting Research $40,613-630$.

Cragg, John G., and Stephen G. Donald, 1993, Testing identifiability and specification in instrumental variable models, Economteric Theory 9, 222-240.

Daniel, Naveen D., Spencer Martin, and Lalitha Naveen, 2004, The hidden cost of managerial incentives: Evidence from the bond and stock markets, Working paper, Georgia State University and Arizona State University.

Datta, Sudip, Mai Iskandar-Datta, and Kartik Raman, 2005, Managerial stock ownership and the maturity structure of corporate debt, Journal of Finance 60, 2333-2350.

Davidson, Russell, and James G. MacKinnon, 1993, Estimation and Inference in Econometrics (Oxford University Press, New York).

Denis, J. David., and Vassil T. Mihov, 2003, The choice among bank debt, non-bank private debt, and public debt: Evidence from new corporate borrowings, Journal of Financial Economics 70, 3-28.

Diamond, Douglas W., 1991, Debt maturity structure and liquidity risk, Quarterly Journal of Economics 106, 709-737.

Diamond, Douglas W., 1993, Seniority and maturity of debt contracts, Journal of Financial Economics 33, 341-368.

Easterwood, John C., and Palani-Rajan Kadapakkam, 1994, Agency conflicts, issue costs, and debt maturity, Quarterly Journal of Business and Economics 33, 69-80. 
Erickson, Merle, Michelle Hanlon, and Edward L. Maydew, 2006, Is there a link between executive equity incentives and accounting fraud? Journal of Accounting Research 44, 113-143.

Fama, Eugene F., and Merton H. Miller, 1972, The Theory of Finance (Holt, Rinehart, and Winston, New York).

Faulkender, Michael, and Mitchell A. Petersen, 2006, Does the source of capital affect capital structure? Review of Financial Studies 19, 45-79.

Graham, John R., and Campbell R. Harvey, 2001, The theory and practice of corporate finance: Evidence from the field, Journal of Financial Economics 60, 187-243.

Graham, John R., and Lillian F. Mills, 2008, Using tax return data to simulate corporate marginal tax rates, Journal of Accounting and Economics 46, 366-388.

Graham, John R., and Daniel A. Rogers, 2002, Do firms hedge in response to tax incentives? Journal of Finance 57, 815-839.

Greene, William H., 2003, Econometric Analysis (Pearson Education, New Jersey).

Guay, Wayne R., 1999, The sensitivity of CEO wealth to equity risk: An analysis of the magnitude and determinants, Journal of Financial Economics 53, 43-71.

Guedes, Jose, and Tim Opler, 1996, The determinants of the maturity of corporate debt issues, Journal of Finance 51, 1809-1833.

Hall, Brian J., and Jeffrey B. Liebman, 1998, Are CEOs really paid like bureaucrats? Quarterly Journal of Economics 113, 653-691.

Hanlon, Michelle, Shivaram Rajgopal, and Terry J. Shevlin, 2004, Large sample evidence on the relation between stock option compensation and risk taking, Working paper, University of Michigan and University of Washington.

Hemmer, Thomas, Steven R. Matsunga, and Terry J. Shevlin, 1996, The influence of risk diversification on the early exercise of stock options by executive officers, Journal of Accounting and Economics 21, 45-68.

Hovakimian, Armen, Tim Opler, and Sheridan Titman, 2001, The debt-equity choice: An analysis of issuing firms, Journal of Financial and Quantitative Analysis 36, 1-24.

Jensen, Michael C., and William H. Meckling, 1976, Theory of the firm: Managerial behavior, agency costs, and ownership structure, Journal of Financial Economics 3, 305-360.

John, Teresa A., and Kose John, 1993, Top-management compensation and capital structure, Journal of Finance 48, 949-974. 
Johnson, Shane A., 2003, Debt maturity and the effects of growth opportunities, managerial discretion, and the security issue decision, Review of Financial Studies 16, 209-236.

Jung, Kooyul, Yong-Cheol Kim, and Rene M. Stulz, 1995, Timing investment opportunities, managerial discretion, and the security issue decision, Journal of Financial Economics 42, 159-185.

Knopf, John D., Jouahn Nam, and John H. Thornton Jr., 2002, The volatility and price sensitivities of managerial stock option portfolios and corporate hedging, Journal of Finance 57, 801-812.

Kole, Stacey R., 1997, The complexity of compensation contracts, Journal of Financial Economics 43, 79-104.

Lambert, Richard A., David F. Larcker, and Robert E. Verrecchia, 1991, Portfolio considerations in valuing executive compensation, Journal of Accounting Research 29, 129-149.

Leland, Hayne E., and Klaus Bjerre Toft, 1996, Optimal capital structure, endogeneous bankruptcy, and the term structure of credit spreads, Journal of Finance 51, 987-1019.

Mariano, Roberto S., 2001, Simultaneous equation model estimators: Statistical properties, in Badi Baltagi, ed.: A Companion to Theoretical Econometrics (Wiley-Blackwell, Oxford).

Merton, Robert C., 1973, Theory of rational option pricing, Bell Journal of Economics and Management Science 4, 141-183.

Moody's Investor Service, 2005, Special comment: CEO compensation and credit risk, July, 110.

Moody's Investor Service, 2007, Special comment: A user's guide to the SEC's new rules for reporting executive pay, April, 1-14.

Myers, Stewart C., 1977, Determinants of corporate borrowing, Journal of Financial Economics $5,147-175$.

Novaes, Walter, and Luigi Zingales, 1995, Capital structure choice when managers are in control: Entrenchment versus efficiency, Working paper, University of Chicago.

Parrino, Robert, and Michael S. Weisbach, 1999, Measuring investment distortions arising from stockholder-bondholder conflicts, Journal of Financial Economics 53, 3-42.

Rajan, Raghuram, and Andrew Winton, 1995, Covenants and collateral as incentives to monitor, Journal of Finance 50, 1113-1146. 
Rajgopal, Shivaram, and Terry Shevlin, 2002, Empirical evidence on the relation between stock option compensation and risk taking, Journal of Accounting and Economics 33, 145-171.

Rogers, W., 1993, Regression standard errors in clustered samples, Stata Technical Bulletin 13, 19-23.

Ross, Stephen A., 2004, Compensation, incentives, and the duality of risk aversion and riskiness, Journal of Finance 59, 205-225.

Sharpe, Steven A., 1991, Credit rationing, concessionary lending, and debt maturity, Journal of Banking and Finance 15, 581-604.

Shaw, Kenneth W., 2007, CEO incentives and the cost of debt, Working paper, University of Missouri, Columbia.

Stock, James H., and Motohiro Yogo, 2004, Testing for weak instruments in linear IV regression, Working paper, Harvard University.

Stohs, Mark Hoven, and David C. Mauer, 1996, The determinants of corporate debt maturity structure, Journal of Business 69, 279-312.

Stulz, Rene M., 2000, Does financial structure matter for economic growth? A corporate finance perspective, Working paper, Ohio State University.

Weber, Joseph, 2006, Discussion of the effects of corporate governance on firms' credit ratings, Journal of Accounting and Economics 42, 245-254.

Yermack, David, 1995, Do corporations award CEO stock options effectively? Journal of Financial Economics 39, 237-269. 
Table I

Sample Distribution

This table shows the time series (Panel A) and industrial (Panel B) distribution of the proportion of short-term debt and the price sensitivities of the CEO's option portfolio. The sample contains 6,825 observations and covers the 1992 to 2005 period. All variables are defined in Appendix B.

Panel A: Medians by fiscal year

\begin{tabular}{|c|c|c|c|c|c|c|c|c|}
\hline Year & $N$ & ST3 & ST5 & \multicolumn{2}{|c|}{ PRCSEN } & \multicolumn{2}{|c|}{ VOLSEN } & EVERAGE \\
\hline 1992 & 135 & 0.309 & 0.466 & \multicolumn{2}{|c|}{1.111} & \multicolumn{2}{|c|}{0.109} & 0.113 \\
\hline 1993 & 398 & 0.320 & 0.489 & \multicolumn{2}{|c|}{1.044} & \multicolumn{2}{|c|}{0.141} & 0.131 \\
\hline 1994 & 516 & 0.347 & 0.549 & \multicolumn{2}{|c|}{0.991} & \multicolumn{2}{|c|}{0.127} & 0.141 \\
\hline 1995 & 533 & 0.303 & 0.547 & \multicolumn{2}{|c|}{1.183} & \multicolumn{2}{|c|}{0.190} & 0.136 \\
\hline 1996 & 557 & 0.287 & 0.557 & \multicolumn{2}{|c|}{1.491} & \multicolumn{2}{|c|}{0.217} & 0.130 \\
\hline 1997 & 559 & 0.292 & 0.568 & \multicolumn{2}{|c|}{1.870} & \multicolumn{2}{|c|}{0.285} & 0.120 \\
\hline 1998 & 489 & 0.306 & 0.574 & \multicolumn{2}{|c|}{1.690} & \multicolumn{2}{|c|}{0.417} & 0.135 \\
\hline 1999 & 463 & 0.358 & 0.593 & \multicolumn{2}{|c|}{1.906} & \multicolumn{2}{|c|}{0.447} & 0.136 \\
\hline 2000 & 469 & 0.432 & 0.666 & \multicolumn{2}{|c|}{2.076} & \multicolumn{2}{|c|}{0.547} & 0.119 \\
\hline 2001 & 481 & 0.354 & 0.604 & \multicolumn{2}{|c|}{2.610} & \multicolumn{2}{|c|}{0.709} & 0.137 \\
\hline 2002 & 542 & 0.315 & 0.548 & \multicolumn{2}{|c|}{2.043} & \multicolumn{2}{|c|}{0.802} & 0.156 \\
\hline 2003 & 566 & 0.307 & 0.541 & & 58 & 0.8 & & 0.143 \\
\hline 2004 & 598 & 0.317 & 0.547 & & 61 & 0.8 & & 0.124 \\
\hline 2005 & 519 & 0.285 & 0.522 & & 60 & 0.7 & & 0.113 \\
\hline & & Panel B & dians by & lustry & & & & \\
\hline Industry & & & $\begin{array}{c}2- \\
\text { digit } \\
\text { SIC }\end{array}$ & $N$ & ST3 & ST5 & PRCSEN & J VOLSEN \\
\hline Food an & oducts & & 20 & 258 & 0.335 & 0.553 & 4.239 & 0.432 \\
\hline Tobacco & & & 21 & 5 & 0.339 & 0.541 & 2.496 & 1.253 \\
\hline Textile $n$ & & & 22 & 69 & 0.316 & 0.588 & 1.031 & 0.107 \\
\hline Apparel & ts made & & 23 & 93 & 0.512 & 0.701 & 1.603 & 0.208 \\
\hline Lumber & roducts & & 24 & 52 & 0.249 & 0.429 & 3.271 & 0.589 \\
\hline Furnitur & & & 25 & 74 & 0.276 & 0.568 & 2.418 & 0.525 \\
\hline Paper an & ducts & & 26 & 192 & 0.285 & 0.464 & 1.374 & 0.436 \\
\hline Printing, & and all & & 27 & 214 & 0.322 & 0.648 & 2.618 & 0.564 \\
\hline Chemica & d produ & & 28 & 731 & 0.381 & 0.659 & 2.805 & 0.628 \\
\hline Petroleu & ind relat & & 29 & 100 & 0.228 & 0.393 & 4.151 & 1.121 \\
\hline Rubber : & neous $\mathrm{p}$ & lucts & 30 & 100 & 0.354 & 0.656 & 1.932 & 0.280 \\
\hline Leather & product & & 31 & 38 & 0.526 & 0.887 & 0.407 & 0.117 \\
\hline Stone, $\mathrm{cl}$ & ad conc & & 32 & 53 & 0.248 & 0.659 & 1.266 & 0.223 \\
\hline Primary & tries & & 33 & 197 & 0.245 & 0.524 & 0.984 & 0.238 \\
\hline Fabricat & oducts & & 34 & 172 & 0.352 & 0.616 & 1.259 & 0.306 \\
\hline Machine & puter eq & & 35 & 562 & 0.440 & 0.706 & 1.809 & 0.478 \\
\hline Electron & electric & & 36 & 565 & 0.396 & 0.742 & 2.260 & 0.421 \\
\hline Transpo & oment & & 37 & 227 & 0.340 & 0.529 & 1.946 & 0.408 \\
\hline Measuri & $\mathrm{g}$, and $\mathrm{c}$ & nstruments & 38 & 478 & 0.449 & 0.850 & 2.996 & 0.515 \\
\hline Miscella & facturir & & 39 & 73 & 0.418 & 0.634 & 3.647 & 0.564 \\
\hline Railroad & & & 40 & 40 & 0.170 & 0.335 & 4.972 & 1.953 \\
\hline Highway & transpo & & 41 & 6 & 0.179 & 0.977 & 0.614 & 0.172 \\
\hline Motor $\mathrm{fr}$ & ortation & ousing & 42 & 74 & 0.411 & 0.756 & 2.845 & 0.172 \\
\hline Water tr & & & 44 & 36 & 0.169 & 0.415 & 1.229 & 0.557 \\
\hline Transpo & & & 45 & 96 & 0.264 & 0.426 & 1.542 & 0.409 \\
\hline
\end{tabular}


Transportation services

$\begin{array}{llllll}47 & 21 & 0.590 & 1.000 & 14.130 & 0.439\end{array}$

Continued from Table I

Communications

Electric, gas, and sanitary services

Wholesale trade-durable goods

$\begin{array}{llllll}48 & 190 & 0.272 & 0.415 & 3.604 & 1.134\end{array}$

$\begin{array}{llllll}49 & 883 & 0.256 & 0.372 & 0.436 & 0.151\end{array}$

Wholesale trade-non-durable goods

$\begin{array}{llllll}50 & 237 & 0.342 & 0.672 & 1.511 & 0.325\end{array}$

Building materials and hardware

$\begin{array}{llllll}51 & 115 & 0.349 & 0.530 & 1.522 & 0.363\end{array}$

General merchandise stores

$\begin{array}{llllll}52 & 41 & 0.158 & 0.785 & 7.522 & 0.155\end{array}$

Food stores

$\begin{array}{llllll}53 & 147 & 0.262 & 0.453 & 5.351 & 0.844\end{array}$

Automotive dealers and gasoline service stations

$\begin{array}{llllll}54 & 78 & 0.254 & 0.526 & 1.624 & 0.328\end{array}$

Apparel and accessory stores

$\begin{array}{llllll}55 & 60 & 0.595 & 0.836 & 2.993 & 0.224\end{array}$

Home furniture and furnishings

$\begin{array}{llllll}56 & 149 & 0.309 & 0.538 & 2.199 & 0.412\end{array}$

Eating and drinking places

$\begin{array}{lllll}57 & 80 & 0.396 & 0.619 & 3.166\end{array}$

0.775

Miscellaneous retail

$\begin{array}{lllll}58 & 161 & 0.366 & 0.714 & 1.939\end{array}$

0.342

$\begin{array}{llllll}59 & 158 & 0.389 & 0.629 & 3.144 & 0.556\end{array}$


Table II

Summary Statistics

This table shows the summary statistics for our dependent and right-hand-side variables in the maturity regression. The sample contains 6,825 observations and covers the 1992 to 2005 period. All variables are defined in Appendix B.

\begin{tabular}{lccccccc}
\hline Variable & Mean & Std Dev & Min & $25 \%$ & $50 \%$ & $75 \%$ & Max \\
\hline ST3 & 0.398 & 0.308 & 0.000 & 0.157 & 0.321 & 0.589 & 1.000 \\
ST5 & 0.583 & 0.306 & 0.000 & 0.347 & 0.560 & 0.888 & 1.000 \\
PRCSEN & 6.914 & 17.160 & 0.017 & 0.689 & 1.894 & 5.487 & 132.340 \\
VOLSEN & 1.108 & 1.913 & 0.000 & 0.112 & 0.408 & 1.158 & 11.446 \\
SIZE & 10182.7 & 26408.9 & 25.095 & 916.6 & 2414.1 & 7632.2 & 449110.2 \\
LEVERAGE & 0.154 & 0.124 & 0.000 & 0.052 & 0.132 & 0.236 & 0.522 \\
ASSET_MAT & 11.619 & 10.280 & 0.769 & 4.395 & 7.846 & 15.394 & 45.425 \\
OWN & 0.024 & 0.057 & 0.000 & 0.001 & 0.003 & 0.014 & 0.328 \\
M/B & 1.888 & 1.146 & 0.803 & 1.193 & 1.508 & 2.133 & 7.593 \\
TERM & 1.535 & 1.137 & -0.440 & 0.570 & 1.360 & 2.550 & 3.550 \\
REG_DUM & 0.114 & 0.317 & 0.000 & 0.000 & 0.000 & 0.000 & 1.000 \\
ABNEARN & 0.006 & 0.100 & -0.432 & -0.012 & 0.006 & 0.023 & 0.512 \\
STD_RET & 0.064 & 0.046 & 0.011 & 0.034 & 0.051 & 0.080 & 0.260 \\
RATE_DUM & 0.604 & 0.489 & 0.000 & 0.000 & 1.000 & 1.000 & 1.000 \\
ZSCORE_DUM & 0.861 & 0.346 & 0.000 & 1.000 & 1.000 & 1.000 & 1.000 \\
\hline
\end{tabular}




\section{Table III}

\section{Average Corporate Bond Yield Spreads and Summary Statistics}

This table shows the summary statistics for the bond pricing sample. The sample contains 268,400 day-bond observations based on the 1994 to 2005 period. All variables are defined in Appendix B.

\begin{tabular}{|c|c|c|c|c|c|c|c|c|c|}
\hline \multicolumn{10}{|c|}{ Panel A: Average corporate bond yield spread (\%) broken down by maturity } \\
\hline Maturity & & AAA & AA & A & $\mathrm{BBB}$ & & & B & $\mathrm{CCC}$ \\
\hline Short (1- 7 years) & & 0.359 & 0.533 & 0.644 & 1.01 & & & 2.826 & 5.671 \\
\hline Medium (7-15 years) & & 0.534 & 0.730 & 1.006 & 1.54 & & & 4.483 & 7.212 \\
\hline Long ( $15-30$ years) & & 0.612 & 0.829 & 1.125 & 1.72 & & & 4.810 & 8.659 \\
\hline \multicolumn{10}{|c|}{ Panel B: Summary statistics } \\
\hline Variable & Mean & $\begin{array}{l}\text { Std } \\
\text { Dev }\end{array}$ & Min & $5 \%$ & $25 \%$ & $50 \%$ & $75 \%$ & $95 \%$ & $\operatorname{Max}$ \\
\hline SPREAD & 1.640 & 1.750 & 0.312 & 0.465 & 0.783 & 1.086 & 1.688 & 4.720 & 11.651 \\
\hline$M A T$ & 14.682 & 7.385 & 2.386 & 3.814 & 7.718 & 15.211 & 21.182 & 25.959 & 28.116 \\
\hline$L M A T$ & 2.520 & 0.627 & 0.870 & 1.339 & 2.044 & 2.722 & 3.053 & 3.257 & 3.336 \\
\hline LPRCSEN & 1.998 & 0.933 & 0.251 & 0.608 & 1.315 & 1.843 & 2.672 & 3.499 & 4.966 \\
\hline LVOLSEN & 1.343 & 0.707 & 0.000 & 0.253 & 0.862 & 1.298 & 1.824 & 2.521 & 3.141 \\
\hline$S T D_{-} R E T$ & 1.822 & 0.815 & 0.765 & 0.918 & 1.255 & 1.595 & 2.200 & 3.302 & 5.572 \\
\hline$A V G \_R E T$ & 0.060 & 0.150 & -0.396 & $0 . \overline{184}$ & -0.027 & 0.058 & 0.145 & 0.309 & 0.512 \\
\hline RATING & 12.431 & 3.328 & 2.000 & 5.500 & 11.000 & 14.000 & 14.000 & 17.000 & 19.000 \\
\hline ROS & 0.155 & 0.087 & -0.024 & 0.046 & 0.096 & 0.136 & 0.202 & 0.317 & 0.422 \\
\hline LEVERAGE & 0.189 & 0.111 & 0.012 & 0.045 & 0.105 & 0.166 & 0.264 & 0.406 & 0.477 \\
\hline INTCOVERAGE & 1.895 & 0.706 & 0.000 & 0.745 & 1.463 & 1.843 & 2.294 & 3.055 & 3.850 \\
\hline COUPON & 7.666 & 1.321 & 3.800 & 5.400 & 6.875 & 7.625 & 8.750 & 9.700 & 10.200 \\
\hline ILLIQUIDITY & 0.161 & 0.258 & 0.023 & 0.031 & 0.039 & 0.047 & 0.070 & 0.844 & 1.000 \\
\hline ISSUE_SIZE & 5.335 & 0.628 & 3.219 & 4.605 & 5.011 & 5.298 & 5.704 & 6.215 & 6.908 \\
\hline BENCHMARK_TREAS & 4.727 & 0.816 & 2.873 & 3.325 & 4.250 & 4.732 & 5.149 & 6.260 & 7.010 \\
\hline$Y L D C R V \_S L O P E$ & 1.208 & 0.965 & -0.260 & $0 . \overline{0}$ & 0.190 & 1.310 & 2.160 & 2.480 & 2.640 \\
\hline EURO_TREAS_SPREAD & 0.219 & 0.138 & 0.030 & 0.060 & 0.110 & 0.180 & 0.310 & 0.490 & 0.700 \\
\hline
\end{tabular}




\section{Table IV}

\section{Relation between Debt Maturity and CEO Portfolio Price/Volatility Sensitivities}

This table shows the pooled regression results for two specifications. In the first (second) specification, the dependent variable is ST3 (ST5). The sample contains 6,825 observations and covers the 1992 to 2005 period. All variables are defined in Appendix B. Statistical significance is based on Rogers (1993) industry-year clustered standard errors. $* * *, * *$, and * denote significance at the $1 \%, 5 \%$, and $10 \%$ levels, respectively.

\begin{tabular}{|c|c|c|c|c|c|}
\hline \multirow{3}{*}{$\begin{array}{l}\text { Independent } \\
\text { variables }\end{array}$} & \multirow{3}{*}{ Predicted signs } & \multicolumn{4}{|c|}{ Dependent variables } \\
\hline & & \multicolumn{2}{|l|}{ ST3 } & \multicolumn{2}{|l|}{ ST5 } \\
\hline & & Coefficient estimate & $p$-value & Coefficient estimate & $p$-value \\
\hline Intercept & & $1.4281^{* * *}$ & 0.000 & $1.2059^{* * *}$ & 0.000 \\
\hline LPRCSEN & - & $-0.0385^{* * *}$ & 0.000 & $-0.0179^{* *}$ & 0.012 \\
\hline LVOLSEN & + & $0.0309^{* * *}$ & 0.001 & $0.0277^{* * *}$ & 0.003 \\
\hline LSIZE & - & $-0.1558^{* * *}$ & 0.000 & $-0.0777^{* * *}$ & 0.000 \\
\hline LSIZE2 & + & $0.0090^{* * *}$ & 0.000 & $0.0041^{* * *}$ & 0.001 \\
\hline LEVERAGE & - & $-1.1068^{* * *}$ & 0.000 & $-0.6251^{* * *}$ & 0.000 \\
\hline ASSET_MAT & - & $-0.0026^{* * *}$ & 0.000 & $-0.0036^{\star * *}$ & 0.000 \\
\hline$O W N$ & + & $0.4562^{* * *}$ & 0.000 & $0.1567^{*}$ & 0.093 \\
\hline$M / B$ & + & -0.0021 & 0.714 & -0.0044 & 0.382 \\
\hline TERM & - & 0.0014 & 0.699 & -0.0049 & 0.209 \\
\hline$R E G \_D U M$ & - & 0.0108 & 0.429 & $-0.0501^{* * *}$ & 0.001 \\
\hline$A B N \bar{E} A R N$ & + & -0.0171 & 0.648 & 0.0253 & 0.500 \\
\hline STD_RET & + & 0.0163 & 0.889 & $0.2232^{* *}$ & 0.036 \\
\hline RATE_DUM & - & $-0.0945^{* * *}$ & 0.000 & $-0.1413^{* * *}$ & 0.000 \\
\hline ZSCORE_DUM & - & $-0.1194^{\star * *}$ & 0.000 & $-0.047^{* * *}$ & 0.000 \\
\hline$R_{a d j}^{2}$ & & \multicolumn{2}{|l|}{0.251} & \multicolumn{2}{|l|}{0.226} \\
\hline$N$ & & \multicolumn{2}{|l|}{6,825} & \multicolumn{2}{|l|}{6,825} \\
\hline
\end{tabular}




\section{Table V}

\section{Relation between Debt Maturity and CEO Portfolio Price/Volatility Sensitivities,}

Joint Determination of Maturity and Leverage

This table shows results for the two-equation system allowing joint determination of maturity and leverage based on GMM. The sample contains 6,825 observations and covers the 1992 to 2005 period. For brevity, only the debt maturity equation estimations are reported. Debt maturity is measured as ST3 and ST5. All variables are defined in Appendix B. ***,**, and * denote significance at the $1 \%, 5 \%$, and $10 \%$ levels, respectively.

\begin{tabular}{|c|c|c|c|c|c|}
\hline \multirow{3}{*}{$\begin{array}{l}\text { Independent } \\
\text { variables }\end{array}$} & \multirow{3}{*}{ Predicted signs } & \multicolumn{4}{|c|}{ Dependent variables } \\
\hline & & \multicolumn{2}{|l|}{ ST3 } & \multicolumn{2}{|l|}{ ST5 } \\
\hline & & Coefficient estimate & $p$-value & Coefficient estimate & $p$-value \\
\hline Intercept & & -0.8225 & 0.596 & -2.5835 & 0.156 \\
\hline LPRCSEN & - & $-0.0829^{* * *}$ & 0.000 & $-0.0698^{* * *}$ & 0.004 \\
\hline LVOLSEN & + & $0.0984^{* *}$ & 0.014 & $0.1269^{* * *}$ & 0.009 \\
\hline LSIZE & - & 0.4047 & 0.267 & $0.8355^{*}$ & 0.051 \\
\hline LSIZE2 & + & -0.0246 & 0.258 & $-0.0505^{\star *}$ & 0.049 \\
\hline LEVERAGE & - & $-1.2759^{* * *}$ & 0.000 & -0.3228 & 0.421 \\
\hline ASSET_MAT & - & $-0.0016^{\star * *}$ & 0.001 & $-0.0026^{\star * *}$ & 0.000 \\
\hline$O W N$ & + & $1.0197^{* * *}$ & 0.000 & $0.7855^{* * *}$ & 0.008 \\
\hline$M / B$ & + & -0.0037 & 0.796 & 0.0113 & 0.486 \\
\hline TERM & - & -0.0002 & 0.966 & $-0.0058^{*}$ & 0.094 \\
\hline$R E G \_D U M$ & - & -0.0035 & 0.855 & $-0.0982^{* * *}$ & 0.000 \\
\hline$A B N \bar{E} A R N$ & + & 0.0146 & 0.707 & 0.0526 & 0.193 \\
\hline$S T D \_R E T$ & + & 0.0853 & 0.765 & $0.5645^{*}$ & 0.085 \\
\hline$R A T E \_D U M$ & - & $-0.1165^{\star \star *}$ & 0.008 & $-0.2245^{\star \star *}$ & 0.000 \\
\hline ZSCORE_DUM & - & $-0.0807^{*}$ & 0.077 & 0.0185 & 0.736 \\
\hline$R_{a d j}^{2}$ & & \multicolumn{2}{|l|}{0.182} & \multicolumn{2}{|l|}{0.204} \\
\hline$N$ & & \multicolumn{2}{|l|}{6,825} & \multicolumn{2}{|l|}{6,825} \\
\hline
\end{tabular}




\section{Table VI \\ Relation between Debt Maturity and CEO Portfolio Price/Volatility Sensitivities, Change Regressions}

This table shows the results of the change regressions. $\Delta$ is used as a prefix to denote the change. In the first (second) specification, the dependent variable is the change in ST3 (ST5). The sample contains 5,513 observations and covers the 1993 to 2005 period. All variables are defined in Appendix B. Statistical significance is based on Rogers (1993) year clustered standard errors. $* * *, * *$, and $*$ denote significance at the $1 \%, 5 \%$, and $10 \%$ levels, respectively.

\begin{tabular}{|c|c|c|c|c|c|}
\hline \multirow{3}{*}{$\begin{array}{l}\text { Independent } \\
\text { variables }\end{array}$} & \multirow{3}{*}{ Predicted signs } & \multicolumn{4}{|c|}{ Dependent variables } \\
\hline & & \multicolumn{2}{|l|}{$\triangle S T 3$} & \multicolumn{2}{|l|}{$\triangle S T 5$} \\
\hline & & Coefficient estimate & $p$-value & Coefficient estimate & $p$-value \\
\hline Intercept & & $0.0058^{*}$ & 0.093 & 0.0014 & 0.530 \\
\hline$\triangle L P R C S E N$ & - & $-0.0440^{* * *}$ & 0.003 & $-0.0259^{* *}$ & 0.025 \\
\hline$\triangle L V O L S E N$ & + & $0.0483^{* *}$ & 0.012 & $0.0247^{*}$ & 0.090 \\
\hline$\triangle L S I Z E$ & - & -0.0831 & 0.176 & 0.0647 & 0.291 \\
\hline$\triangle L S I Z E 2$ & + & 0.0018 & 0.650 & -0.0029 & 0.475 \\
\hline$\triangle L E V E R A G E$ & - & $-1.1325^{* * *}$ & 0.000 & $-0.6638^{* * *}$ & 0.000 \\
\hline$\triangle A S S E T \_M A T$ & - & -0.0007 & 0.449 & -0.0005 & 0.614 \\
\hline$\triangle O W N$ & + & $0.7247^{* * *}$ & 0.007 & $0.5065^{* *}$ & 0.015 \\
\hline$\Delta M / B$ & + & -0.0009 & 0.940 & $-0.0289^{* *}$ & 0.017 \\
\hline$\triangle T E R M$ & - & -0.0040 & 0.339 & $-0.0073^{* *}$ & 0.020 \\
\hline$\triangle A B N E A R N$ & + & -0.0226 & 0.377 & $0.0553^{* *}$ & 0.026 \\
\hline$\triangle S T D \_R E T$ & + & 0.0376 & 0.798 & 0.1341 & 0.302 \\
\hline$\triangle R A T E \_D U M$ & - & $-0.1201^{* * *}$ & 0.000 & $-0.1929^{* * *}$ & 0.000 \\
\hline$\triangle Z S C O R E_{-} D U M$ & - & $-0.1242^{* * *}$ & 0.000 & $-0.0571^{* * *}$ & 0.000 \\
\hline$R_{a d j}^{2}$ & & \multicolumn{2}{|l|}{0.095} & \multicolumn{2}{|l|}{0.063} \\
\hline$N$ & & \multicolumn{2}{|l|}{5,513} & \multicolumn{2}{|l|}{5,513} \\
\hline
\end{tabular}


Table VII

\section{Relation between Debt Maturity and CEO Portfolio Price/Volatility Sensitivities,} Joint Determination of Maturity, Leverage, Compensation, and Investment

This table examines the robustness of the relation between debt maturity and managerial incentives by allowing for the joint determination of maturity, compensation, capital structure, and investment policies based on GMM. The sample contains 6,180

firm-year observations. All variables are defined in Appendix B. ***,**, and * denote significance at the 1\%, 5\%, and 10\% levels, respectively. 